\title{
Fitting Regression Models for Sustainable Management of Non-Timber Forest Products in Forests and Private Lands: A Case Study from Mid-Western Region of Nepal
}

\author{
Bishnu Hari Pandit ${ }^{1}$ and Laxman Ghimire ${ }^{2}$ \\ Corresponding author : Bishnu Hari Pandit \\ Email : bhpandit@ntc.com.np
}

\begin{abstract}
This study examines the constraining factors for sustainable management of Non-Timber Forest Products (NTFPS) in both community and private forests in Dang, Rolpa and Pyuthan Districts of mid-western Nepal. Four CFUGs were selected from each of the study districts, and NTFP inventory was done. A total of 259 households were randomly sampled for household data collection. Two Focus Group Discussions (FGDs) were held in each district and Key Informant survey was done to assess preliminary information and data. Two regression models were fitted to investigate the causes of sustainable management of NTFPS. The report revealed that Non-Timber Forest Product (NTFP) cultivation initiated by local farmers in the past have indicated that farmers have planted some species of NTFPs (such as Cinnamon tamala, Swertia, Zanthoxylum, Sapindus) in their farmlands and other community forest lands in the study districts. A regression analysis of constraining factors explored in a household survey revealed that cultivation of NTFP species is significantly influenced by household labour force engaged in cultivation in agriculture on marginal lands and their affiliation with community based local institutions $\left(R^{2}=56 \%\right)$. While constraining factors for sustainable management of NTFP in government and community forests are distance from home to forest, food production; active labour force, training on forest management, and household labour force involved in agriculture $\left(R^{2}=66 \%\right)$. Recommendations are made for sustainable management of NTFPs in forest and private lands.
\end{abstract}

Key Words : Sustainable management, NTFPs, CFUGs, Regression Models.

\section{Introduction}

It is a well accepted fact that in many instances, people in Nepal and in other developing countries have not been able to prevent forest resources from degradation under the changing socio-economic, institutional and national policy contexts which invariably

\footnotetext{
${ }^{1}$ Principal, Kathmandu Forestry College, Email bhpandit29@gmail.com

${ }^{2}$ Faculty, Statistics, Kathmandu Forestry College, Email laxmanghi@gmail.com
} 
influence the fundamental parameters of sustainable natural resource management (Blaikie and Brookfield, 1987; Bac, 1998; Ostrom et al., 1999; Pandit and Thapa, 2004). For instance, there is a tendency to attribute rapid deforestation in the mountains of Nepal to the nationalization of forests in 1957. This is true to some extent, as this action led to the abolition of local people's customary rights to use and manage forests, but it should be noted that the major proportion of forest in the mountains had actually disappeared before the 1950s (Ives and Messerli, 1989) when forests were largely under local rather than state control. As noted by Ostrom et al. (1999), degradation may be partly attributed to the lack of rules specifying how much and when forests are used; creating and financing formal monitoring arrangements, and establishing sanctions for non-conformance (Pandit and Thapa, 2004). The problem of forest degradation is partly attributed to small landholdings and scarce non-farming employment opportunities that force mountain people to encroach on forests for expansion of agricultural land to meet the food requirement for their ever increasing household members (Thapa and Weber, 1995; Pandit and Thapa, 2004).

What is not much realized in regard to studies on sustainable management of Non-Timber Forest Products in community managed and private forests? In principle, in the case of open access resources in community managed forest, for example, the resources are in principle subject to degrade more. Depending on their value, the rate of degradation of the resources would be higher in community forests compared to private lands, as the tendency of local people is to save resources in private lands and exploit more from common property resources (Pandit, 2003). The degradation of NTFPs in community forest is basically dependent on value of the species and the demand available. For instance species with relatively high demand and value have become vulnerable to extinction (IFAD, 1999; Subedi, 1997; Olsen, 1998; Gautam, 2000).

While in the case of private forests, NTFP domestication is one of the means that saves NTFP to degrade from government and community forests. The cultivation of NTFP is perceived to be dependent on various factors such as land size, animal holdings, family labour force, agriculture practice and availability of resources in national forests nearby settlement, which needs to be investigated. Several studies document farmers' efforts to regenerate different types of NTFP species in privately owned farmlands (Gilmour, 1989; Yadav, 1992; Garforth, Malla, Neupane, \& Pandit, 1999; Malla; Pandit, 2001; Neupane et al., 2002). Although a considerable amount of research on technical matters of adoption in agriculture has been conducted, including those related to fodder and firewood trees (Hossion \& Crouch, 1992; Neupane et al.), less attention has been paid to the factors influencing domestication of NTFP species in Nepal, which is crucial for sustainable management of NTFPs in Government and community forests.

In view of these gaps in knowledge about the factors that are responsible for sustainable management of NTFPs in community forests and private lands, this study was conducted in Dang, Rolpa and Pyuthan districts of mid-western regions of Nepal under support of the University Grant Commission, Nepal. 


\section{RESEARCH METHODOLOGY}

\section{Study area}

Three districts namely Dang, Rolpa and Pyuthan were selected for this research. These districts were purposively selected as to have community forest (CFs) representing three different climatic settings. The guiding principle for this kind of selection was to have different NTFPs species with variation in climatic conditions so that the findings of the study could represent at least the western development region and the geographical region having similar climatic settings (Figure 1).

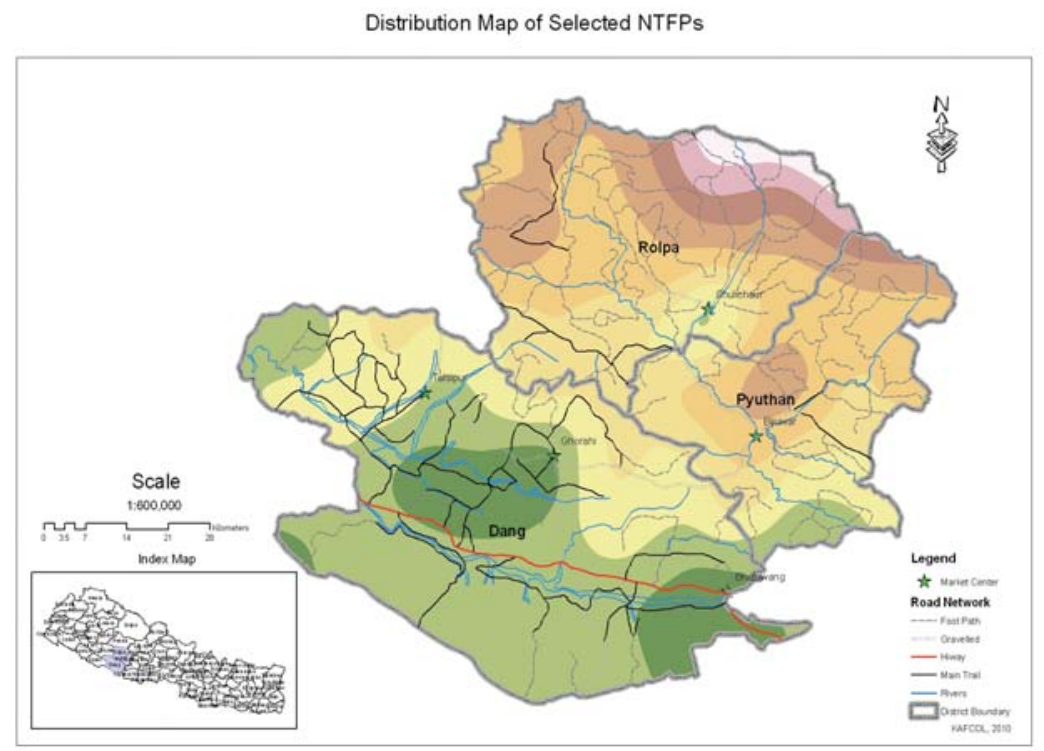

Figure 1: Map of Study Districts

\section{Community Forest User Groups (CFUGs) selection}

Firstly, the research team identified number of CFUGs handed over to the community from the respective District Forest Office (DFO). Secondly, we found top five highly traded NTFPs in the study districts from the DFO records of past three years. Thirdly, we found the distribution pattern of these selected five NTFP species collected and traded from each of the three study districts. This was done by the help of DFO personnel, federation of community forest users- Nepal (FECOFUN) officials, NGOs and local community leaders involved in NTFP sector in these districts. The total number of CF handed over to local community in three districts was 1241 (447 from Dang, 412 from Pyuthan and 382 from Rolpa) (Table 1). 
Table 1: Basic characteristics of study districts

\begin{tabular}{|c|c|c|c|}
\hline Description & Dang & Pyuthan & Rolpa \\
\hline 1. Area in sq. km & 2955 & 1328 & 1879 \\
\hline 2. $\quad$ Altitude $(\mathrm{m})$ & $213-2058 \mathrm{~m}$ & $359-3659 \mathrm{~m}$ & $701-3639 \mathrm{~m}$ \\
\hline 3. Climate & $\begin{array}{c}\text { Tropical, Sub- } \\
\text { tropical and } \\
\text { Temperate Climate }\end{array}$ & $\begin{array}{c}\text { Subtropical, } \\
\text { temperate Climate }\end{array}$ & $\begin{array}{l}\text { Sub-tropical, mild } \\
\text { temperate, cool } \\
\text { temperate }\end{array}$ \\
\hline $\begin{array}{l}\text { 4. Number } \\
\text { of VDC/ } \\
\text { Municipality }\end{array}$ & $39 / 2$ & 49 & 52 \\
\hline 5. Number of Ilaka & 13 & 11 & \\
\hline $\begin{array}{ll}6 . & \begin{array}{l}\text { Number of } \\
\text { constituencies }\end{array} \\
\end{array}$ & 5 & 2 & 2 \\
\hline $\begin{array}{l}\text { 7. Total Forest } \\
\text { Area (ha) }\end{array}$ & 192955 & 72690 & \\
\hline 8. No of CFs & 447 & 412 & 382 \\
\hline 9. Area of CF (ha) & 95226 & 40241 & \\
\hline 10. Population & 462380 & 212484 & 188144 \\
\hline - Female & 228970 & 114098 & 97192 \\
\hline - $\quad$ Male & 233409 & 98390 & 90922 \\
\hline
\end{tabular}

Source: District Forest Office Record, 2010

In the beginning, one VDC from Pyuthan District, and two VDCs each from Dang and Rolpa were identified as a cluster or a stratum. Each cluster represented at least one agroclimatic region. For example, two VDCs (Kavre and Ghorahi) selected in Dang represent warm tropical region, one VDC (Maranthana) selected from Pyuthan District represents sub-tropical region, and two VDCs (Libang and Kotgaon) from Rolpa District represent sub-tropical to temperate region. From each cluster/stratum, four CFUGs were chosen based on availability of NTFP resources (rich, medium, fair and poor) (Table 2). From Dang District, Jumlepani Gadi, Lwange Bhatkule, Mouwalek and Basanta Hariyali CFUGs were selected. Similarly from Pyuthan District, Palukathan Kandip, Sattale Marayang, Darejeunikhola and Rajakharka CFUGs and from Rolpa, Mewang, Reugha, Dangdhara and Jhola Bang were selected (Table 2). After selection of these CFUGs, NTFP resource inventory was done in each of the community forests. 
Table 2: Household and area of the selected CFUGs

\begin{tabular}{|c|c|c|c|c|c|}
\hline \multicolumn{2}{|c|}{ District/Name of FUG } & VDC/Ward & HHs & Area (ha) & $\begin{array}{c}\text { Resource } \\
\text { availability } \\
(\mathrm{a}, \mathrm{b}, \mathrm{c} \& \mathrm{~d})\end{array}$ \\
\hline \multirow{4}{*}{ ڤ્心 } & $\begin{array}{l}\text { 1. Jumle Pani } \\
\text { Gadhi }\end{array}$ & Kavre - 3 & 198 & 129 & b \\
\hline & $\begin{array}{l}\text { 2. Lwange } \\
\text { Bhatkule }\end{array}$ & Kavre - 4 & 292 & 386 & $\mathrm{c}$ \\
\hline & 3. Mouwalek & Kavre $-1,2,3$ & 247 & 66 & $\mathrm{~d}$ \\
\hline & 4. Basanta Hariyali & Ghorahi - 6 & 368 & 225 & $\mathrm{a}$ \\
\hline \multirow{4}{*}{ 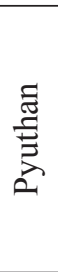 } & $\begin{array}{l}\text { 5. Palukathan } \\
\text { Kandip }\end{array}$ & Maranthan - 8 & 87 & 20 & $\mathrm{c}$ \\
\hline & $\begin{array}{l}\text { 6. Sattale } \\
\text { Marayang }\end{array}$ & Maranthan - 4 & 155 & 44.6 & $\mathrm{~B}$ \\
\hline & 7. Darejeunikhola & Maranthan - 5 & 163 & 35.50 & $\mathrm{a}$ \\
\hline & 8. Rajakharka & Maranthan - 1 & 134 & 44.50 & $\mathrm{~d}$ \\
\hline \multirow{4}{*}{$\frac{\pi}{2}$} & 9. Mewang & Liwang - 7 & 139 & & $\mathrm{c}$ \\
\hline & 10. Reugha & Liwang $-2,3,4,5$ & 317 & 434 & $\mathrm{~d}$ \\
\hline & 11. Dangdhara & Kotgaun - 6 & 152 & 242 & $\mathrm{~b}$ \\
\hline & 12. Jhola Bang & Kotgaun - 3,4 & 151 & 343 & $\mathrm{a}$ \\
\hline \multicolumn{2}{|r|}{ Total } & & 2280 & 1925 & \\
\hline
\end{tabular}

Resource availability: $a=$ rich; $b=$ medium; $c=$ fair and $d=$ poor

\section{Sampling techniques used for household survey}

In each cluster, sample households were randomly selected by using a random number table. Following method designed by Arkin and Colten (1963), a sample size of 259 has been calculated for a total of 2280 households at $95 \%$ confidence level, with $\pm 04 \%$ level of precision and $85 \%$ rate of occurrence.

$$
n=\frac{N Z^{2} P(1-P)}{N d^{2}+Z^{2} P(1-P)} \quad=259 \text { households }
$$

Where, $\mathrm{n}=$ sample size

$$
\begin{aligned}
& \mathrm{N}=\text { total number of the forest user groups households in whole clusters } \\
& \mathrm{Z}=\text { confidence level }(95 \%) \\
& \mathrm{P}=\text { estimated proportion of the population }(85 \%) \\
& \mathrm{d}=\text { error limit }(4 \%)
\end{aligned}
$$

These sampled households were proportionally distributed based on the population in each of the districts for survey. Table 3 shows the distribution of sample households in each of the study districts. 
Table 3: Distribution of surveyed households

\begin{tabular}{|c|c|c|c|c|c|c|}
\hline \multirow[t]{2}{*}{ District } & \multicolumn{4}{|c|}{ Sample HHs by Sex } & \multicolumn{2}{|c|}{ Total surveyed HHs } \\
\hline & Male & Percent & Female & Percent & Number & Percent \\
\hline Rolpa & 69 & 42 & 33 & 35 & 102 & 39 \\
\hline Pyuthan & 44 & 27 & 38 & 41 & 82 & 32 \\
\hline Dang & 53 & 31 & 22 & 24 & 75 & 29 \\
\hline Total & 166 & 100 & 93 & 100 & 259 & 100 \\
\hline
\end{tabular}

\section{Data collection}

\section{Household survey}

A detailed questionnaire was developed for household survey. The questionnaire aimed at collecting data on social (Caste, Gender etc), economic (income sources and other livelihood endowments), ecological (involvement in NTFPs management and promotion), institutional (affiliation to NTFPs related organizations like cooperatives, CBOs, NGOs etc), and marketing (local people's involvement in NTFP trade and NTFP based enterprise). It also aimed at assessing the perceptions of individual farmers towards cultivation of NTFPs in private land versus existing cereal crops. Farmers' views and perception on cultivation and sustainable management of NTFPs were assessed.

\section{Focus Group Discussion}

From random selection, the real picture of the economic contribution of NTFPs to the poor households and to ethnic minorities and untouchable caste (dalits) can't be assessed. Focus Group Discussions were held at local (CFUG) and district levels. A total of 6 FGDs (two each district) was conducted. Participants of the FGD meeting were also invited for detail interview and interview was held using checklist for Key Informant Survey (KIS).

\section{RESULTS}

\section{NTFP Availability}

The key NTFP species in the study area are indigenous to the forests or grasslands, and some are grown in private lands. In this paper, we basically identified species that have commercial value and are collected from government managed forests and community forests, and produced from private lands by local people. The collection of NTFPs to fulfil basic household needs is a long established, traditional practice in the study area. Local collectors, with the exception of license holders, do not need to pay tax and can sell NTFPs easily to village-based or road head traders. Normally, wholesale traders based at district markets have to pay the stipulated royalty to the DFO when transporting NTFPs to the regional city of Nepalgunj and some time to Mahendranagar. There is strong competition among people within catchment of three districts in collecting NTFPs because of attractive 
benefits combined with the opportunity to sell NTFPs in their villages. Normally, competition is intense for high- value NTFPs such as Kutki (Picrorhiza scrophulariiflora), Satuwa (Paris polyphylla), Kurilo (Asparagus resamosus) as each collector wants to collect as much as possible of these medicinal plants. Many NTFPs are available in the catchment area of three districts.

Based on FGD meeting held, 20 NTFP species are found dominant in upper elevation zone $(>1500$ meter amsl) and 15 are dominant in lower elevation $(<1500$ meter amsl) of the study area (Table 4).

Table 4: NTFP availability in catchment areas of five Local CFCs

\begin{tabular}{|c|c|c|c|c|}
\hline \multicolumn{2}{|r|}{ NTFP species } & Dang & Pyuthan & Rolpa \\
\hline \multirow{10}{*}{8} & 1. Aconitum bisma (Bisma) & - & - & + \\
\hline & 2. Acorus calamus (Bojho) & - & + & + \\
\hline & 3. Astilbe rivularis (Thulo Okhato) & - & - & + \\
\hline & 4. Berberis asiatica (Chutro) & + & + & + \\
\hline & 5. Bergenia ciliata (Pakhanbed) & - & + & + \\
\hline & 6. Dactylorhiza hatagirea (Panchaunle) & - & - & - \\
\hline & 7. Daphne bholua (Lokta) & - & ++ & + \\
\hline & 8. Girardiana diversifolia (Allo) & - & + & + \\
\hline & 9. Juniperus species (Dhup) & - & - & + \\
\hline & 10. Lycopodium clavatum (Nagbeli) & & - & \\
\hline \multirow{3}{*}{ 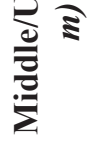 } & 11. Nardostachys grandiflora (Jatamansi) & & - & \\
\hline & 12. Parmelia species (Jhyau) & + & + & ++ \\
\hline & 13. Persea sp (Kaulo) & + & ++ & + \\
\hline \multirow{8}{*}{ 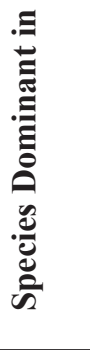 } & 14. Paris polyphylla (Satuwa) & - & - & ++ \\
\hline & 15. Picrorhiza scrophulariiflora (Kutaki) & - & - & - \\
\hline & 16. Rheum australe (Padamchal) & - & - & - \\
\hline & 17. Rhododendron anthopogon (Sunpati) & - & - & - \\
\hline & 18. Swertia chirayita (chiretta) & - & + & + \\
\hline & 19. Taxus baccata (Lauthsalla) & - & - & - \\
\hline & 20. Thysanolaena maxima (Amliso) & + & + & + \\
\hline & 21. Valeriana jatamansi (Sugandawal) & - & + & + \\
\hline
\end{tabular}




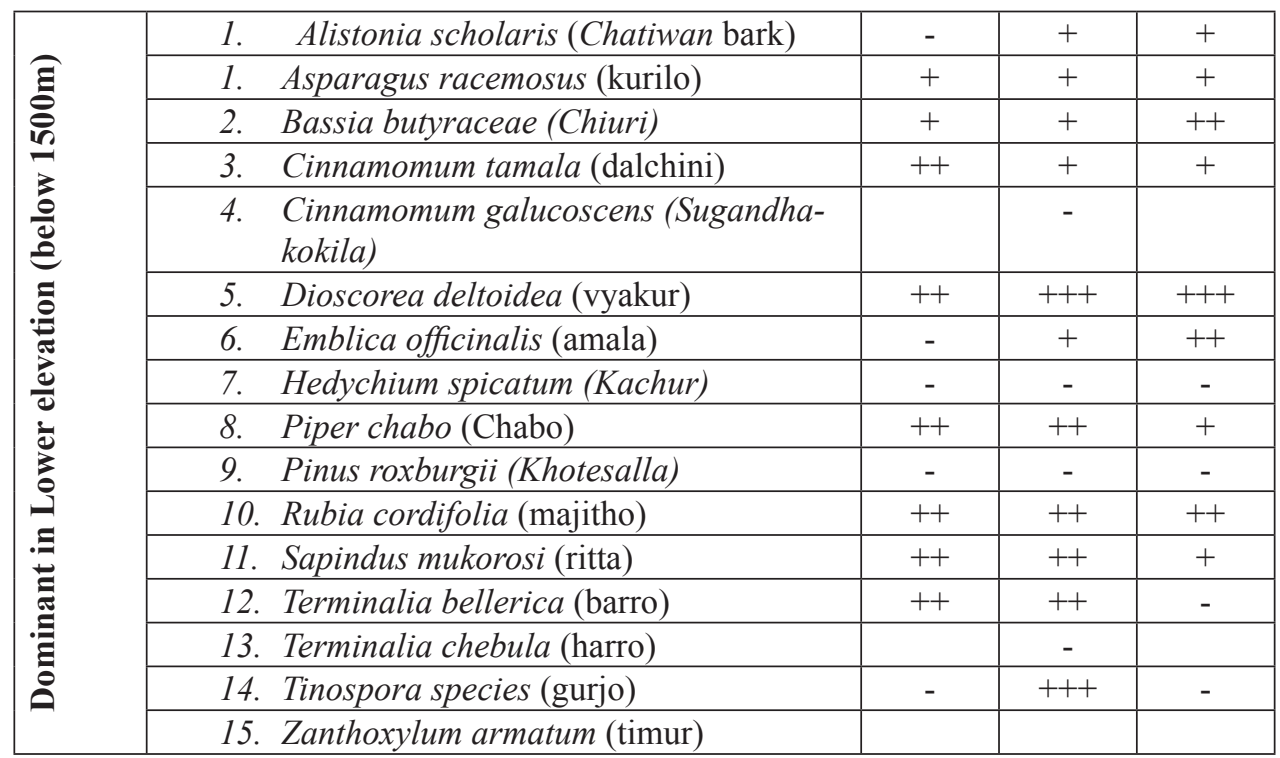

Source: Field survey, 2010

Note: $-=$ Not available $;=$ = Available in low volume $;++=$ Available in moderate volume; and $+++=$ Available in high volume

\section{Major NTFPs collected and traded}

Most households in the study area cannot fulfil their minimum subsistence requirements through agriculture, which is the primary economic activity. Given the poor soil quality and small landholding size of about 0.1 hectare per capita, on average, people cannot produce sufficient food for themselves, to ensure supply for the whole year. Off-farm employment opportunities are scarce. Under these constraints, local people would seek alternative means of livelihood, including periodic out-migration and on-farm yet non-farm activities like NTFP collection. The latter has become an attractive alternative means of supplementing income for most households where there is access. Three major district wholesale trading points (one point per district) have been identified in three study districts (Table 5). Most NTFPs of Rolpa District pass through Shulichaour to Bijuwar of Pyuthan district, which ultimately arrive at Bhaluwang of Dang district. NTFPs collected from lower parts of Rolpa and whole Dang District is collected at Ghorai and some at Tulsipur of Dang district. From these both routes, most NTFPs are transported to Nepalgunj.

Shulichour of Rolpa District: This is the main NTFP market niche or centre of Rolpa district. The potential NTFPs that can be collected and traded in high volume or quantity from this sub-centre include Tejpat (Cinnamomum tamala), Pakhanebed (Bergenia ciliate), Ritha (Sapindus mukurossi), Allo (Girardiana diversifolia), Timur (Zanthoxylum armatum), 
Jhayu (Parmelia nepalensis), Chiuri (Bassia butyraceae), sugandhawal (Valeriana jatamansi), Sugandhakokila (Persea spp) and Pine resin (Pinus spp) in smaller volume not recorded by DFO. Other NTFPs, which fetch high price but available in low volume include, Panchaunle (Dactylorhiza hatagirea), Kutki (Picrorhiza scrophulariiflora), and Satuwa (Paris polyphylla). This center exports the lowest volume of NTFPs (152 t) of the three districts (Table 5).

Bijuwar of Pyuthan District: This center receives largest quantities of NTFP from Pyuthan District and smaller quantities from Rolpa District. This centre is very important in terms of NTFP trade to be handled by local communities. The major MAP species collected and traded from this centre are Pine reson (Pinus spp), rittha (Sapindus mukurossi), Tejpat (Cinnamomum tamala), Chutro, Pakahanbed, Kachur (Hedychium spicatum), Jhyau, Amala (Phyllanthus emblica), Chiraito (Swertia chirayita), Timur (Zanthoxylum armatum), and Kaulo bark (Persea sp) and Kaphal bark. This center exports more than half (420 t) of the total volume of NTFPs traded from three districts.

Ghorahi of Dang: This centre receives MAPs from lower part of Rolpa and northwest part of of Doti District. NTFPs from eastern Dang are exported directly to Nepalgunj via Bhaluwang. The major MAP/NTFP species growing and collected from this centre are Pine resin (Pinus spp.), Sugandhakokila, Amala, Rittha, Tejpat, Chiuri, Bojo, Timur, Pakhanbed and Chiraito (in smaller volume), which makes trading of $182 \mathrm{t}$.

Table 4: Volume of major NTFP $(\mathrm{Kg})$ traded from three market centers

\begin{tabular}{|ll|c|c|c|}
\hline \multicolumn{2}{|c|}{ NTFPs } & \multicolumn{3}{|c|}{ Market center } \\
\cline { 3 - 5 } & $\begin{array}{c}\text { Dang } \\
\text { Ghorahi }\end{array}$ & $\begin{array}{c}\text { Pyuthan } \\
\text { Bijuwar }\end{array}$ & $\begin{array}{c}\text { Rolpa } \\
\text { Shulichour }\end{array}$ \\
\hline 1. & Pine resin & 49686 & 370324 & - \\
\hline 2. & Ritha & 50160 & 7000 & 50000 \\
\hline 3. & Timur & 22273 & 27200 & 50000 \\
\hline 4. & Tejpat & 24263 & 3400 & 50000 \\
\hline 5. & Kaulo bark & - & 12500 & - \\
\hline 6. & Sugangdha Kokila & 35744 & - & 2200 \\
\hline & Total & 182,126 & 420,424 & 152,200 \\
\hline
\end{tabular}

Source: Field survey, 2010

\section{Model Specification}

This section identifies a number of variables which affect improvements in NTFP domestication. The link between various socioeconomic variables and number of NTFP species domesticated and volume of NTFP collected are investigated using multiple regression analysis. A stepwise multiple regression analysis was used to influence the level of NTFP cultivation in private lands and volume of NTFPs collected from community and 
government forests by a set of independent variables: $\mathrm{X}_{1}, \mathrm{X}_{2}, \ldots, \ldots, \mathrm{X}_{\mathrm{n}}$. The two regression models are specified as follows:

$\mathrm{Y}_{1}=\mathrm{b}_{\mathrm{o}}+\mathrm{b}_{1} \mathrm{X}_{1}+\mathrm{b}_{2} \mathrm{X}_{2}+\ldots \mathrm{b}_{\mathrm{n}} \mathrm{X}_{\mathrm{n}},(1)$

$\mathrm{Y}_{2}=\mathrm{b}_{\mathrm{o}}+\mathrm{b}_{1} \mathrm{X}_{1}+\mathrm{b}_{2} \mathrm{X}_{2}+\ldots \mathrm{b}_{\mathrm{n}} \mathrm{X}_{\mathrm{n}},(2)$

Where:

$\mathrm{Y}_{1}=$ the number of NTFP species (first dependent variable);

$\mathrm{Y}_{2}=$ volume of NTFP collected from forests;

$\mathrm{b}_{\mathrm{o}}$ is the intercept; and $\mathrm{b}_{1}, \mathrm{~b}_{2} \ldots$ are coefficients of explanatory variables $\mathrm{X}_{1}, \mathrm{X}_{2} \ldots \mathrm{X}_{\mathrm{n}}$.

Each model was constructed using the stepwise probability criteria of $F$ to enter $\leq .05$ and probability of $F$ to remove $\geq .10$.

Dependent Variables-The NTFPs in the study area were grown dispersedly across various plots, some planted in fallow lands, some on terrace risers and some on edges of farmlands and swidden plots. Mostly they were found on marginal fallow lands, called kharbari. Therefore, the number of NTFP species growing in each type of lands were added together and total NTFP number was defined.

NTFP cultivation in private land- Model $1\left(\mathbf{Y}_{1}\right)$ : Average number of NTFP species grown in private lands.

NTFP collection from forests - Model $2\left(\mathbf{Y}_{2}\right)$ : Average volume (in $\mathrm{kg}$ ) of NTFP collected from community and government forests.

Independent Variables- The influence of independent variables on the dependent variables was examined using regression analysis. Fifteen independent variables were selected and defined in Table 5.

Table 5 showing the list of independent variables

\begin{tabular}{|l|l|}
\hline Variables & Description of variables \\
\hline 1. Social group & Social group belonging to Dalit/Janajati and other \\
\hline 2. Private land (Khet) & Area in Hectare \\
\hline 3. Rented land (Khet) & Area in Hectare \\
\hline 4. Private land (Bari) & Area in Hectare \\
\hline 5. Rented land (Bari) & Area in Hectare \\
\hline 6. Marginal land (registered) & Area in Hectare \\
\hline 7. Marginal Land (not registered) & Area in Hectare \\
\hline 8. Agriculture labor force & $\begin{array}{l}\text { Household }(\mathrm{HH}) \text { labor force involved in agriculture } \\
\text { (no./HH) }\end{array}$ \\
\hline 9. NTFPs related training & Training attended by the HH head (no. in 2008) \\
\hline 10. Active labor force & Aged 11-59 at home (no./HH) \\
\hline 11. Food production & Kg/person/year (composite yield of all crops) \\
\hline 12. Farm income & Cash income from farm sources (Rs/person/year \\
\hline
\end{tabular}




\begin{tabular}{|l|l|}
\hline Variables & Description of variables \\
\hline 13. Off-farm income & $\begin{array}{l}\text { Net cash income from off-farm sources (including } \\
\text { remittances) }\end{array}$ \\
\hline 14. Distance from forest & Distance from home to forest (in Kilometre) \\
\hline 15. Institutional membership & No. of family members affiliated to local institutions \\
\hline
\end{tabular}

Source: Field survey, 2010

Model \# 1- Factors Influencing the NTFP cultivation in private land: -Of the 15 independent variables regressed, Four (4) variables, "household labour force", "marginal lands", "Number of family members affiliated to local institution", and "food production" were found statistically significant in this model (Table 6). All these variables combinedly explain about $56 \%$ of the total variation (Table 6). All variables are positively associated with cultivation of NTFP species. With the increase of household labour force, there is a tendency to grow more number of NTFPs on farmlands. It is obvious that the high number of the labour force tend to work with larger non-registered marginal land, where more number of NTFP species are grown. Organizational affiliation is highly influencing variable for NTFP cultivation on private lands. It means that CFUG members are more motivated to protect and domesticate NTFP species in private land. Of the four significant variables, 'food production' is the least significant variable but has greater role in management of NTFP in private land. When local people have large volume of food, they tend to go for less harvesting of NTFPs that saves the stock of NTFPs in private and also in community and government forests. In order to sustain the NTFP production in private land, these four variables are very essential.

Table 6: Variables in the equation -Model-I- NTFP cultivation in private lands

\begin{tabular}{|c|c|c|c|c|c|c|c|c|c|}
\hline \multirow{2}{*}{$\begin{array}{c}\text { Regression } \\
\text { model } \\
\text { of NTFP } \\
\text { cultivation } \\
\text { on }\end{array}$} & \multirow{2}{*}{$\begin{array}{c}\text { Constant/ } \\
\text { coefficients } \\
\text { of fitted } \\
\text { model }\end{array}$} & \multicolumn{3}{|c|}{ t test } & \multirow[b]{2}{*}{ 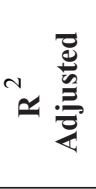 } & \multirow[b]{2}{*}{ 导 } & \multicolumn{3}{|c|}{ ANOVA } \\
\hline & & 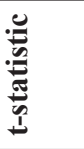 & 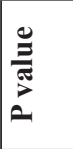 & 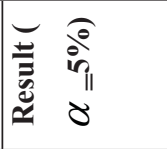 & & & 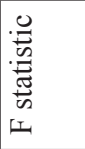 & $\begin{array}{l}\frac{0}{3} \\
\frac{\pi}{\pi} \\
2\end{array}$ & 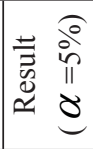 \\
\hline Constant & -107.29 & -5.44 & 0.00 & Significant & \multirow{5}{*}{0.56} & \multirow{5}{*}{136.32} & \multirow{5}{*}{55.92} & \multirow{5}{*}{0.00} & \multirow{5}{*}{ 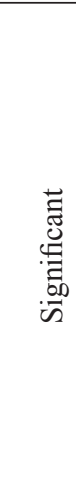 } \\
\hline $\begin{array}{l}\text { Household } \\
\text { labour force }\end{array}$ & 48.65 & 5.53 & 0.00 & Significant & & & & & \\
\hline $\begin{array}{l}\text { Marginal } \\
\text { land (Not } \\
\text { registered) }\end{array}$ & 15.69 & 6.07 & 0.00 & Significant & & & & & \\
\hline $\begin{array}{l}\text { No of family } \\
\text { members } \\
\text { affiliated } \\
\text { with local } \\
\text { institutions }\end{array}$ & 38.65 & 3.65 & 0.00 & Significant & & & & & \\
\hline $\begin{array}{l}\text { Food } \\
\text { production }\end{array}$ & 0.09 & 2.51 & .01 & Significant & & & & & \\
\hline
\end{tabular}

Source: Field survey, 2010 
Model \# 2: Factors Influencing NTFP collection from forests- The stepwise logistic regression analysis reveals that five (5) variables are significant predictors of NTFP collection from forests in the study area. The significantly influencing variables include "distance from home to forest", "food production", "active labour force", "training", and "household labor force involved in agriculture" (Table 7). The $\mathrm{R}^{2}$ values increase with the addition of each independent variable, and each independent variable selected in this model has reasonable explanatory power. All these five variables explained above explain more than $66 \%$ of the $\mathrm{R}^{2}$ value in the model (Table 7 ).

Table 7: Variables in the equation- model -II: NTFP collection from forests

\begin{tabular}{|c|c|c|c|c|c|c|c|c|c|}
\hline \multirow[b]{2}{*}{$\begin{array}{c}\text { Regression } \\
\text { model of NTFP } \\
\text { collection }\end{array}$} & \multirow{2}{*}{ 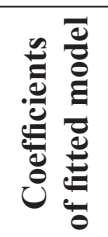 } & \multicolumn{3}{|c|}{$T$ test } & \multirow[b]{2}{*}{ 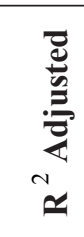 } & \multirow[b]{2}{*}{$\begin{array}{l}\dot{0} \\
\dot{0} \\
\dot{0}\end{array}$} & \multicolumn{3}{|c|}{ ANOVA } \\
\hline & & 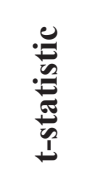 & อ & 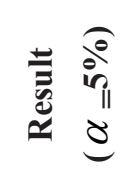 & & & 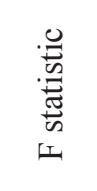 & $\underset{\substack{\frac{0}{3} \\
\frac{\pi}{2}}}{0}$ & 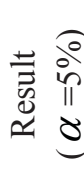 \\
\hline Constant & 16.32 & .37 & 0.71 & $\begin{array}{l}\text { Not Sig- } \\
\text { nificant }\end{array}$ & \multirow{5}{*}{.664} & \multirow{5}{*}{125.41} & \multirow{5}{*}{69.46} & \multirow{5}{*}{0.00} & \multirow{5}{*}{ 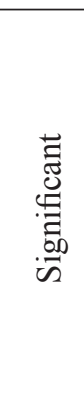 } \\
\hline $\begin{array}{l}\text { Distance from } \\
\text { home to forest }\end{array}$ & -60.82 & -4.47 & 0.00 & $\begin{array}{l}\text { Signifi- } \\
\text { cant }\end{array}$ & & & & & \\
\hline Food production & 0.14 & 4.31 & 0.00 & $\begin{array}{l}\text { Signifi- } \\
\text { cant }\end{array}$ & & & & & \\
\hline $\begin{array}{l}\text { Active labour } \\
\text { force }\end{array}$ & 37.64 & 4.37 & 0.00 & $\begin{array}{l}\text { Signifi- } \\
\text { cant }\end{array}$ & & & & & \\
\hline $\begin{array}{l}\text { Training at- } \\
\text { tended by } \mathrm{HH}\end{array}$ & 93.064 & 3.71 & 0.00 & $\begin{array}{c}\text { Signifi- } \\
\text { cant }\end{array}$ & & & & & \\
\hline $\begin{array}{l}\text { Household } \\
\text { labour force } \\
\text { involved in } \\
\text { agriculture }\end{array}$ & 24.19 & 3.04 & 0.003 & $\begin{array}{l}\text { Signifi- } \\
\text { cant }\end{array}$ & & & & & \\
\hline
\end{tabular}

"Distance from home to forest" appears to be negatively influencing variable in the model (Table 7). It means that with the increasing distance, local people tend to avoid NTFP collection and those who are close or nearby forest extract more NTFPs. "Training attended by households" is related to knowledge and those who have received training tend to protect NTFP resources in the forest. One might assume that such knowledge and skill obtained from training would interface with the planting of NTFP species in farmlands. As elsewhere in the mountains of Nepal (Neupane et al., 2002; Pandit, 2003), farmers in the study area are not growing any kind of NTFP trees, particularly bamboo and bushes on the bunds and walls of upland and paddy terraces because of the fear of negative shade effect of trees on field crops. 


\section{CONCLUSION}

This study has examined the feasibility of integrating NTFP species in private land for their sustainable management and use. Several influential factors have been identifiedincluding labor force, food production, marginal land size and number of family members affiliated to local institution are responsible for sustainable cultivation of NTFPs in private lands. In order to increase the NTFP cultivation in private lands and improve sustainable management of NTFP in forests, it is recommended to hand over the use and management responsibility government forest to local people, particularly to poorest of the poor, as in community forestry. It follows from the fact that increasing number of institutional affiliation and training tend to protect more NTFP resources in forests and farmlands. Therefore, institutional capacity building is the one that is necessary for sustainable management of NTFP resources in forest and private lands.

\section{REFERENCES}

Bac, M. 1998. Property rights regimes and management of resources. Natural Resources Forum 22(4): 263-269.

Baland, J.M., \& Platteau, J.P. 1996. Halting degradation of natural resources: is there a role for rural communities? Oxford: Clarendon Press.

Blaikie, P., \& Brookfield, H. 1987. Land degradation and society. Methuen London and New York.

Garforth, C., John, Y.B., Malla, Neupane,R.P. and Pandit, B.H.1999. Socioeconomic Factors and Agroforestry Improvements in the Hills of Nepal. Mountain Research and Development 19 (3): $273-278$.

Gautam, D.K. 1999. Promoting Non-Timber Forest Products in the Hills of Nepal: A Case Study of Jethal and Attarpur villages in Sindhu Palchok District, Nepal, Asian Institute of Technology, Thailand, AC-99-9, pp.44-55.

Gilmour, D.A.1989. Forest resources and indigenous management in Nepal. Working Paper No. 17, Est West Center Honolulu, Hawaii Hossion, A.M. and Crouch, B.R.1992. Patterns and determinants of adoption of farm practices: Some evidence from Bangladesh. Agricultural Systems 38: 1-15.

IFAD. 1999. Programming a future for Asia's upland poor: Proceedings of the International Fund for Agricultural Development Reality Check Consultation, Bangkok, 19-21 April.

Ive, J.D. and Messerli, B. 1989. The Himalayan Dillemma: Reconciling development and conservation. United nations University, ROUTLEDGE, London and New York.

Lacuna-Richman, C. (2002). The socioeconomic significance of subsistence non-wood forest products in Leyte, Philippines. Environmental Conservation 29 (2): 252-263. 
Malla, Y.B. 2000. Farmers' tree management strategies in a changing rural economy, and factors influencing decisions on tree growing in Nepal. International Tree Crop Journal 10: 247266.

Neupane, R.P., Sharma, K.R. and Thapa,G.B. 2001. Adoption of agroforestry in the hills of Nepal: a logistic regression analysis. Agricultural Systems 72: 177-196 Olsen, C.S. 1998. The trade in medicinal and aromatic plants from central Nepal to Northern India. Economic Botany 52(3), 279-292.

Ostrom E., Burger, J., Field, C.B. Norgaard, R.B. \& Policansky, D. 1999. Revisiting the commons: Local lessons, global challenges. Science 284(4), 278-282.

Pandit, B.H. and Thapa, G.B.2003. A tragedy of non-timber forest resources in the mountain commons of Nepal. Environmental Conservation 30(3): 283-292

Pandit, B.H., 2003. Prospects of promoting non-timber forest products in the mountains of Nepal. AIT- PhD Thesis- Asian Institute of Technology, Thailand.

Thapa, G.B., \& Weber, K.E. 1995. Natural resource degradation in small watershed in Nepal: Complex issues and remedial measures. Natural Resources Forum 19 (4), 285-296.

Yadav, Y.1992. Farming-forestry-livestock linkages: a component of mountain farmers' strategies (Nepal). In: Jodha NS, Baskota M. and Pratap T (eds.) Sustainable Mountain Agriculture Vol. 1, Perspective and Issues. Oxford and IBH Publishing Co Ltd, New Delhi. 